\title{
An Empirical Analysis of Women's Promotion in Japanese Companies: Comparison with Chinese and Korean Cases
}

\author{
Hiromi Ishizuka \\ Sanno College/Sanno University, Tokyo, Japan \\ Email: ISHIZUKA_Hiromi@mi.sanno.ac.jp
}

Received 9 May 2016; accepted 19 June 2016; published 22 June 2016

Copyright (C) 2016 by author and Scientific Research Publishing Inc.

This work is licensed under the Creative Commons Attribution International License (CC BY). http://creativecommons.org/licenses/by/4.0/

(c) (i) Open Access

\section{Abstract}

The purpose of this study is to contribute to the economic revitalization of Japan by learning from other countries through a consideration of diversity. From Chinese urban areas, we study an example of a fluid labor market, and a firmly rooted movement of women into the workplace. From Korea, even though the male-female disparities are greater than those in Japan, we study a concrete case in terms of the rapid speed of the changing workplace. The framework includes not only promotion at the company level, but also lifestyle at the household level. The study uses the numerical values and analysis is through the Negative Binominal Regression Model. Findings include: 1) in Japan, there is "slow promotion" in the both case of men and women and a "glass ceiling" for women; 2) in China, the decisive male-female disparity is the difference in the "age of fixed retirement". Gender gaps in working conditions are uncommon. Home factors slightly disturb promotions. Tenure is short and there is a fluid labor market. There is a "sticky floor" for women; 3 ) in Korea, the gender gap of graduate's with more than a bachelor's degree is small. Men with no official title are concentrated in the low rank, and have long tenures. There is a "sticky floor" for men. There are two years of compulsory military service for young men. Despite this, many men are promoted to higher managerial positions in their lifetimes.

\section{Keywords}

Promotion, Labor Market, Gender Diversity in Management, Work-Life Balance, Glass Ceiling, Sticky Floor, Negative Binominal Regression Model 


\section{Introduction: Can Women Save Their Country's Economy?}

Japan was ranked the 101st out of 145 countries on the World Economic Forum's Global Gender Gap Index (GGGI) in 2015. Japan has the second largest gender gap among Organization for Economic Cooperation and Development (OECD) countries, next only to Republic of Korea (Korea) which was ranked the 115th. China was ranked the 91st. In these three countries, "the gender gap among managers" in "Economic Participation and Opportunity" is largest (Ishizuka [1]).

Japan is experiencing a population decrease and a financial deficit. As such, high hopes are being pinned on women as a potential workforce and as potential mothers. The government is advocating the "202030" campaign that calls for raising the percentage of women in management positions from the current approximately ten percent to thirty percent by 2020. The current Cabinet has created "Womenomics" as one of the key elements of the economic growth strategy, calling for "creating a society in which women shine," while Japanese companies have just begun taking steps toward Gender Diversity in Management (Ishizuka [2]).

This research is significant because it compares Japan with China and Korea, which represents Asian countries that have enjoyed remarkable economic growth, and whose features are diverse depending on the country. From the example of China's urban areas, this paper studies a case in which a male-female joint system of women moving into the workplace is firmly rooted, and an example of a fluid labor market as the consequences of a "quota system" of a planned economy, even though China is an Asian country with a Confucian mindset. From Korea, even though the male-female disparities are greater than those in Japan, a concrete example in terms of the rapid speed of the changing workplace due to the country's small scale, and the fact that there is intervention by the International Monetary Fund (IMF).

The purpose of this paper is to contribute to the economic revitalization of Japan by learning from other countries through a consideration of diversity, including the differences between men and women known as "Gender Diversity in Management" at the company level. It is based on statistical methods that employ numerical data of company surveys in three countries, and the differences in work-life balance of each country of both men and women including the major factors at the household level, and through a clarification of the mechanisms for promotion.

\section{Framework of Promotion, "Glass Ceiling" and "Sticky Floor"}

This study focuses on promotion to management positions. The words "Glass Ceiling" (GC) and "Sticky Floor" (SF) are used in connection with the disparity in promotions between men and women. Since the "ceiling" is "glass" it is transparent, and therefore it means those constraints that are not visible to women. Since the floor is "sticky", it means women cannot be promoted from the first official post they receive.

Lazear and Rosen [3] proposed a threshold effect hypothesis. The arbitrary woman who is a member of the women's group often has a limitation at the time of promotion. Because those making personnel decisions are often high ranking male managers, they frequently promote individuals that are members of their own group, i.e., men. Men are at an advantageous position because other men are in charge of the promoting within the firm. In addition, Bihagen and Ohls [4] proposed that employers hesitate to hire women because they perceive women as having limited availability due to potential pregnancy and child care complications. If a woman overcomes the threshold effect hypothesis and is at the same level as a man or is even more productive, the woman becomes more dominant.

Empirical economic analysis can be used to study such problems in the economic background of a country. SF phe- nomenon is observed in the UK (Booth, Francesconi and Frank [5]. In Sweden, Hultin [6] stated that the gender gap de- creases in lower positions within a company, and that as a result, higher-ranking positions have a larger gender gap. In addition, Bihagen and Ohls [4] points out that there is a GC in medium and lower managers and that women do not often attain a higher rank in Sweden. Albrecht, Bjorklund, and Vroman [7] suggested the existence of a GC. In India, Duraisamy and Duraisamy [8] derived that SF rather than GC phenomenon is observed in all segments of the labor market. In Dalian, China, Matsushige and Xu [9] inspected the promotion structure of white-collar jobs in companies using an ordered probit model. The continuous service is called factorial one of the promotion.

Figure 1 and Figure 2 are the frame of this study. Consider: 1) that a gender gap known as "Gender Diversity in Management" at the company level exists in the three countries, and the differences in career formation and work-life balance of each country; and 2) a gender gap includes the major factors at the household level, and 


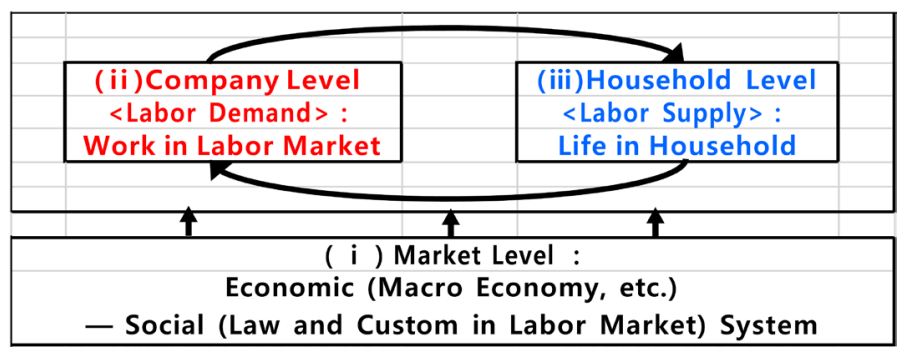

Figure 1. Framework of working women's analysis. Source: Ishizuka [10], Figure 3-4-1.

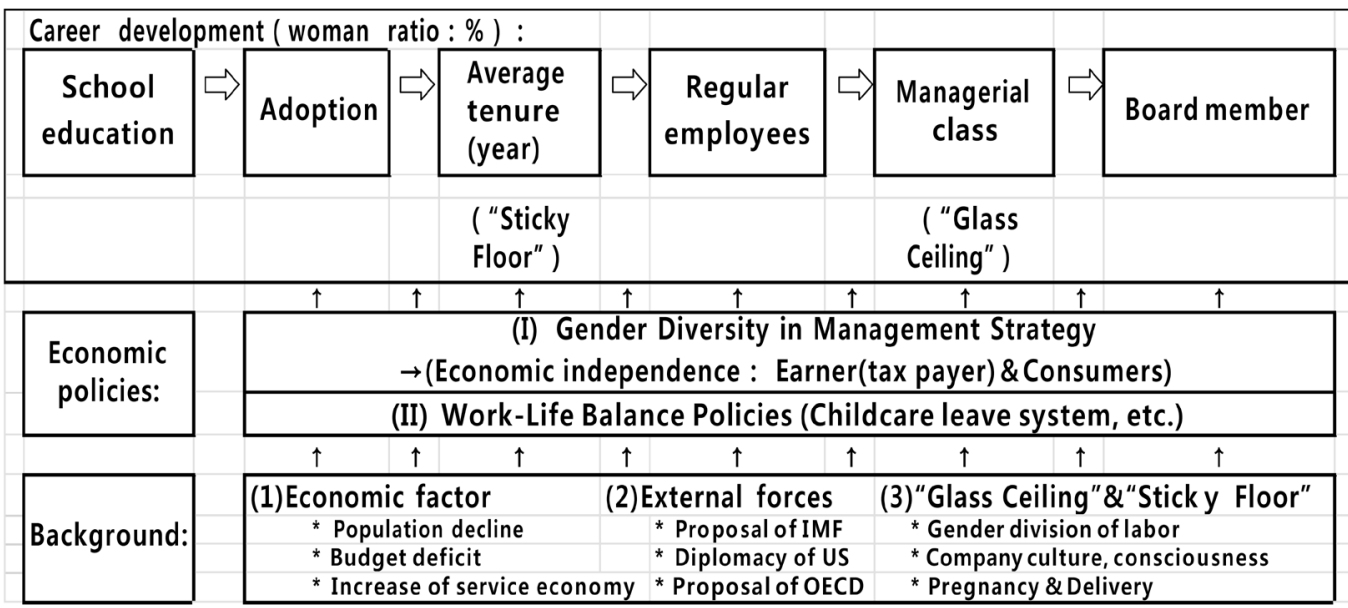

Figure 2. Female careers and the Japanese government's "womenomics". Source: Ishizuka [1], Figure 3.

through a clarification of the mechanisms for promotion. Figure 2 is the career development and replenishment of women in the regular workforce.

\section{Data}

The Japanese company data is from our original "the Corporate Survey on the Human Resources Utilization of Men and Women (Japan) 2015." The data for Chinese and Korean companies is from "the Corporate Survey on the Human Resources Utilization of Men and Women (China, Korea) 2013" of the Ministry of Economy, Trade and Industry and the Research Institute of Economy, Trade and Industry (RIETI) [10] [11], this survey was conducted after the applicants were selected by the project. Based on a theoretical economic model, the analysis is performed using Stata for the econometric model.

The Japanese company surveys began in August 2015, and these are internet surveys that were conducted for managers in charge of personnel. The Chinese and Korean company surveys began in March 2013, and these are interview surveys that were conducted for managers in charge of personnel or higher posts. The final sample included 300 Chinese and 305 Korean companies. The companies that are survey targets are "soft quota (allocation) based on a population or companies with a scale of at least 100 employees". In addition: 1) the three major industrial classifications; 2) company scale (number of employees); 3) the three tiers of cities; and 4) the proportion by form of ownership of the companies have also been moderately considered. The cities in 3 ) above are Beijing, Shanghai, and Guangzhou in Guangdong Province in China, and Seoul, Incheon, and Gyeonggido in Korea and ten percent from other regions. There is a detailed account of the surveys and results in Ishizuka [10].

\section{Real Condition of Promotion and Household Factor by Data Analysis}

\subsection{Common and Different Points of Japan, China, and Korea}

The three neighboring countries are located in northeast Asia and have a Confucianism influenced gender outlook on men's and women's roles in society, and a large gender gap in their economies (Ishizuka [12]). In addi- 
tion, their population is gradually diminishing with declining birthrate and increases in the elderly population (Ishizuka [10]). Japan's population peaked the earliest, in 2008, but China's population is expected to peak by 2030, Korea's by 2035. As for the total fertility rates, they are 1.40 for Japan, 1.55 for China, 1.26 for Korea (2010-2015) [13], and 0.88 for Chinese urban areas [14].

China differs from the other countries because of the quota system of "low wage and gender employment equality" that was introduced into the planned economy of 1949. By "hukou (family registration system) law" of 1958, an urban hukou and a rural hukou are founded. Each firm was employed and located by the Chinese government, and the labor market disappeared. Market liberalization moved with the "Reform and Opening-up Policy" of 1978, state-owned enterprise reform after the mid-1990s, and Chinese GDP was the second in the world in 2010 (Ishizuka [15], Chapter 2). There is now a fluid labor market, and the movement of women into the workplace is firmly rooted in society. However according to Ishizuka [10] [15], wage differentials, occupation gap, and the number of gender differential in technical firms increased with market liberalization. In addition, the number of "developed country-shaped full-time housewives" who are young and whose husbands are not low income increased (Ishizuka [11]).

On the other hand, there are many common points between Japan and Korea. The labor force participation rate of both countries' women is "an M-shaped curve" (Ishizuka [10], Figure 3-4-2. In other words, there is a tendency that a woman quits her job and becomes a full-time housewife. In addition, there is the real condition that the gender division of labor at the home level leads to the gender gap of the workplace in the company level (Ishizuka [16]). However Korea joined the OECD in 1996 because of the Asian currency crisis. The government speedily shifted to practice the OECD policies.

In all of the countries, HM (Higher Manager, department manager), MM (Middle Manager, section manager classes) and LM (Lower Manager, sub-section manager classes) are management positions, and strictly speaking the subsection manager class is not.

In Japan, provisions concerning working hours, rest time, and days off are not applicable to management positions, and there is no obligation to pay extra wages for overtime work. In the case of China, an obligation to pay extra wages for overtime work arises despite the fact that the position is a managerial one, other than some exceptions. The exceptions are workers to whom the "flexible working hour system" is applied. This is a discretionary work system that determines the working hours and rest times in individual cases based on the establishment of standards outside working hours by the company, and it can be applied to the department manager class and employees working outside the office. Here, the statutory working hours in China's Labor Law are eight hours per day and forty hours per week, and the extra wage rate for overtime work is high. In addition, it is necessary to conclude with each individual employee a contract that explicitly indicates the working hours, rest times, days off, and wages. Long working hours have become a problem in Korea and efforts are underway to shorten them, but they are still the longest among the OECD countries (Ishizuka [8]). Starting from 2004, 40 hours per week of statutory working hours have been introduced in stages, and all companies were subject to this only in 2011, and the extra wage rate for overtime work is also low.

\subsection{Managerial Positions of Japan, China, and Korea}

We summarize concrete numerical values of Table 1 . The disparity between men and women in the number of executives, managers, or employees by position has been recognized in three countries, and the male-female discrepancy becomes larger the higher a manager goes in the corporate hierarchy. The discrepancy in Japan is largest, followed by Korea and China in that order. In recent years the "Affirmative Action system" (AA system) has required large Korean companies to set a numerical target for the promotion of women, leading to women being given promotion priority over men (Ishizuka [15], Chapter 6).

A gender gap was found for Japanese middle-sized companies in everything including wages, working hours, years of continuous service, average age, and the rate of graduation from a university. The Korean long working time has become a social concern, but it cannot be said that it appears in the numerical value for a company investigation.

The "average age" of LM (lower manager, a subsection manager), which is an entryway for managerial positions, is the mid-forties for Japan, compared to the mid-thirties in China, a difference of ten years. In the case of HM (Higher Manager, department managers), the average ages were the early fifties in Japan, the mid-forties in 
Table 1. Summary statistics of the corporate level and household level (Japan, China, and Korea).

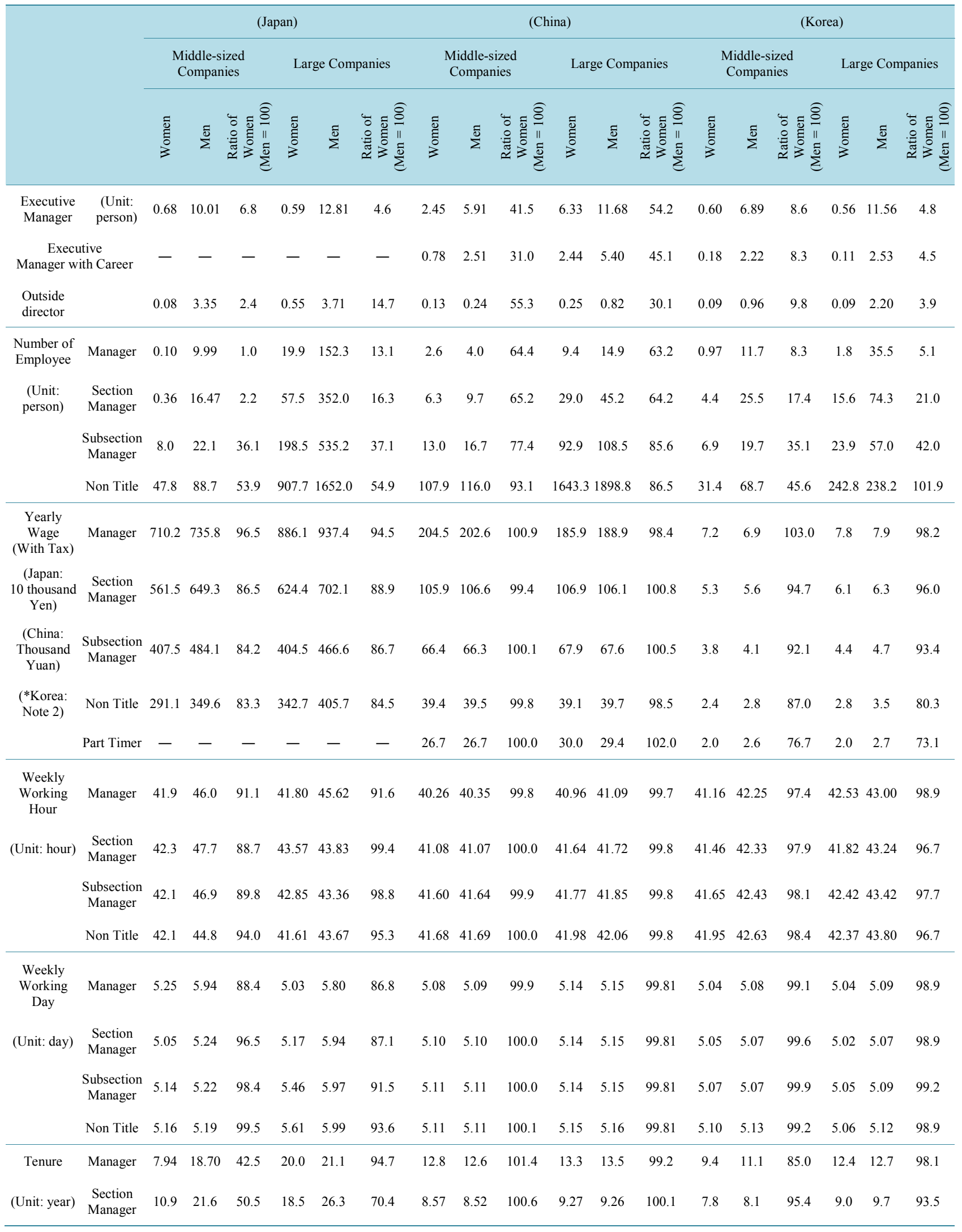




\begin{tabular}{|c|c|c|c|c|c|c|c|c|c|c|c|c|c|c|c|c|c|c|c|}
\hline & $\begin{array}{l}\text { Subsection } \\
\text { Manager }\end{array}$ & 9.3 & 17.1 & 54.3 & 16.4 & 21.1 & 77.8 & 5.50 & 5.35 & 102.9 & 5.62 & 5.68 & 99.0 & 5.47 & 5.45 & 100.4 & 6.0 & 5.7 & 105.1 \\
\hline & Non Title & 9.9 & 13.3 & 74.1 & 13.5 & 14.7 & 91.9 & 3.27 & 3.22 & 101.6 & 3.35 & 3.32 & 100.9 & 3.79 & 3.82 & 99.4 & 4.2 & 5.2 & 80.8 \\
\hline $\begin{array}{l}\text { Average } \\
\text { Age }\end{array}$ & Manager & 47.7 & 48.5 & 98.4 & 53.2 & 54.3 & 98.1 & 41.3 & 43.2 & 95.5 & 39.0 & 41.9 & 93.1 & 43.7 & 46.9 & 93.2 & 44.7 & 46.8 & 95.5 \\
\hline \multirow[t]{4}{*}{$\begin{array}{c}\text { (Unit: } \\
\text { Year-old) }\end{array}$} & $\begin{array}{l}\text { Section } \\
\text { Manager }\end{array}$ & 45.9 & 46.2 & 99.2 & 42.3 & 47.4 & 89.2 & 37.7 & 39.8 & 94.7 & 35.8 & 38.2 & 93.8 & 36.9 & 39.9 & 92.5 & 36.5 & 40.7 & 89.8 \\
\hline & $\begin{array}{l}\text { Subsection } \\
\text { Manager }\end{array}$ & 44.4 & 45.9 & 96.8 & 41.7 & 46.2 & 90.2 & 32.9 & 36.7 & 89.6 & 33.4 & 36.0 & 92.8 & 32.6 & 34.8 & 93.9 & 32.8 & 34.9 & 94.2 \\
\hline & Non Title & 41.1 & 41.4 & 99.4 & 40.9 & 41.4 & 98.7 & 33.6 & 36.0 & 93.2 & 33.3 & 34.5 & 96.4 & 34.9 & 36.5 & 95.8 & 32.8 & 36.4 & 90.2 \\
\hline & Part Timer & 35.6 & 36.7 & 97.0 & 34.7 & 36.1 & 96.1 & 40.1 & 40.3 & 99.3 & 40.1 & 33.5 & 119.4 & 32.5 & 35.7 & 90.9 & 37.6 & 35.4 & 106.3 \\
\hline $\begin{array}{l}\text { Retirement } \\
\text { Age }\end{array}$ & Manager & - & - & - & - & - & - & 50.9 & 60.1 & 84.6 & 51.0 & 60.4 & 84.4 & 57.5 & 57.6 & 99.9 & 58.2 & 57.8 & 100.6 \\
\hline \multirow[t]{3}{*}{$\begin{array}{l}\text { (Unit: } \\
\text { Year-old) }\end{array}$} & $\begin{array}{l}\text { Section } \\
\text { Manager }\end{array}$ & - & - & - & - & - & - & 50.6 & 60.1 & 84.2 & 50.6 & 60.2 & 84.1 & 57.3 & 57.5 & 99.7 & 57.9 & 57.8 & 100.2 \\
\hline & $\begin{array}{l}\text { Subsection } \\
\text { Manager }\end{array}$ & - & - & - & - & - & - & 50.5 & 60.1 & 84.1 & 50.4 & 60.2 & 83.7 & 57.3 & 57.3 & 99.9 & 57.7 & 57.7 & 100.1 \\
\hline & Non Title & - & - & - & - & - & - & 50.5 & 60.1 & 84.1 & 50.4 & 60.1 & 83.8 & 57.5 & 57.5 & 99.9 & 57.8 & 57.9 & 99.9 \\
\hline $\begin{array}{l}\text { University } \\
\text { or above }\end{array}$ & & 8.9 & 26.1 & 34.2 & 83.0 & 221.3 & 37.5 & 87.64 & 96.16 & 91.1 & 930.27 & $\begin{array}{c}1064.1 \\
1\end{array}$ & 87.4 & 30.62 & 76.95 & 39.8 & \multicolumn{2}{|c|}{$\frac{142.9}{7} 228.63$} & 62.5 \\
\hline With Spouse & nit: & 18.5 & 19.2 & 96.5 & 18.5 & 29.2 & 63.4 & 82.56 & 88.88 & 92.9 & 877.86 & 937.79 & 93.6 & 28.22 & 80.85 & 34.9 & \multicolumn{2}{|c|}{$\frac{151.6}{8} 277.53$} & 54.7 \\
\hline $\begin{array}{l}\text { With Child } \\
\text { of } \\
\text { pre-school }\end{array}$ & $\begin{array}{c}\text { person) } \\
\text { ("Regler } \\
\text { Employee) }\end{array}$ & 7.5 & 17.3 & 43.3 & 69.7 & 170.9 & 40.8 & 26.73 & 27.71 & 96.5 & 227.96 & 233.13 & 97.8 & 20.53 & 52.35 & 39.2 & \multicolumn{2}{|c|}{$\begin{array}{c}149.9 \\
8\end{array} 159.40$} & 94.1 \\
\hline $\begin{array}{l}\text { With Child } \\
\text { of } 7-18 \\
\text { years old }\end{array}$ & & 6.9 & 20.9 & 33.0 & 54.8 & 169.4 & 32.4 & 25.38 & 30.54 & 83.1 & 214.19 & 295.64 & 72.4 & 16.49 & 51.51 & 32.0 & \multicolumn{2}{|c|}{68.56190 .87} & 35.9 \\
\hline $\begin{array}{l}\text { University } \\
\text { or above }\end{array}$ & $\begin{array}{l}\text { ('Inside } \\
\text { gender) }\end{array}$ & 12.1 & 18.4 & 66.1 & 51.2 & 66.7 & 76.7 & $65.8 \%$ & $62.0 \%$ & 106.1 & $52.2 \%$ & $51.0 \%$ & 102.4 & $68.7 \%$ & $56.7 \%$ & 121.2 & \multicolumn{2}{|c|}{$50.2 \% 54.3 \%$} & 92.4 \\
\hline \multicolumn{2}{|c|}{ Number of Observation } & & 115 & & & 105 & & & 199 & & \multicolumn{3}{|c|}{101} & & 235 & & \multicolumn{2}{|r|}{70} & \\
\hline
\end{tabular}

Source: The data set of Chinese and Korean companies is "the Corporate Survey on the Human Resources Utilization of Men and Women (China/Korea) 2013" of the Ministry of Economy, Trade and Industry and the Research Institute of Economy, Trade and Industry (RIETI). Japanese company data is "the Corporate Survey on the Human Resources Utilization of Men and Women (Japan) 2015". Note 1. 1) Responses have been obtained as the average figures for 2012 for the wages, actual working hours, and actual number of days worked; 2) The average ages are the result of calculations done by the author, these being 24 years old for " $20 \mathrm{~s}$ and younger", 34 years old for " $30 \mathrm{~s}$ ", 44 years old for " $40 \mathrm{~s}$ " and 54 years old for " $50 \mathrm{~s}$ " in the responses. Note 2. For the annual wages of Korea, the number of the scale is shown in accordance with the following scale. The scale numbers are: 1) Less than 20 million won; 2) 20 to 24 million won; 3) 25 to 29 million won; 4) 30 to 34 million won; 5) 35 to 39 million won; 6) 40 to 44 million won; 7) 45 to 49 million won; 8) 50 to 59 million won; 9) 60 to 69 million won, and 10) 70 million won.

Korea and around forty in China. "Slow promotion" which is one of the characteristics of the Japanese employment system in the broader sense, was introduced.

Although it is relatively small compared to Japan, an overall gender gap in Korea can be observed. However, the difference between men and women in the rate of graduation from a university and above is small, and there was a tendency for women to have higher educational achievement in medium-sized companies. There is a large gender gap for "married persons" for reasons of family, except for those who "have pre-school children" in large companies. The decisive gender gap in China is the difference in the "age of fixed retirement", in addition the difference in the "average age" by position could also be confirmed. In China, the decisive male-female disparity is the difference in the "age of fixed retirement". The gender gap of working conditions is uncommon. The home factor disturbs the promotion slightly. Tenure is short and there is a fluid labor market.

Next, compare "the retirement age". In Japan, sixty years old is the legal retirement age, in addition "the elderly person job security method" of April, 2013 requires employment until sixty-five years. In China, for men 
it is sixty years old, for women it is fifty under the existing circumstances of “the men's and women's retirement system". 1 In Korea, a system for retirement at sixty years of age was introduced in 2016. According to Table 1 , the "actual" age is around fifty-seven years old.

\section{Empirical Analysis of Promotion with Household Level, GDM and WLB}

\subsection{Negative Binominal Regression Model Analysis}

The probability that a promotion occurs is low, and it is an unpredictable phenomenon. I analyze it in a LDV (Limited dependent variable) model. The number of the managerial classes is not negative, but the data is censored and it may concentrate on zero without being able to tell if there is an equilateral value in the case of women. Therefore, I cannot adopt the normal distribution of OLS. There are three potential models for estimation: 1) the "Poisson Regression Model" of the bottleneck to be equal to the average of the dependent variable, or the "Negative Binominal Regression Model" where variance is 2) a quadratic function or 3) a linear function [17].

An expectation of the number of theoretical outbreak:

$$
\ln (Y)=\beta_{0}+\beta_{1} x_{1}+\cdots+\beta_{j} x_{j}+\varepsilon
$$

is estimated by maximum likelihood. Where, $Y$ : number of employees in the official post and gender; $\beta_{0}$ : constant term; $x_{1}$ to $x_{j}$ : explanatory variables; $\beta_{1}$ to $\beta_{j}$ : parameters; $\varepsilon$ : error term. The explanatory variables are "human capital theory": average age, university graduation ratio, tenure and square of tenure, "a company attribute": middle-sized company dummy, tertiary industry dummy, and city dummy, "a life (household level) factor": spouse ratio, preschool children ratio, and under high-school ratio, "the personnel affairs' view about the factor that there are few women managers" as the company culture. As a result of estimating three types of models, we use (2) "Negative Binominal Regression Model" with "variance is a quadratic function",

\subsection{Results}

In the estimated analysis of the Japanese company: 1) "slow promotion" was accepted by both men and women; 2) the home factor for a spouse and child decreases female NO (no title employee) and LM (Lower Manager: a subsection manager). If women choose not to marry, and give priority to their work they have a higher change of being promoted higher than LM; 3) the company culture of "there is little female manager because advancement in life will is higher in a man" only improves male employees' odds of being promoted. The home factor has a big gender gap, and the "glass ceiling" is accepted.

In the estimated analysis of the Chinese company: 1) the "sticky floor" phenomenon is accepted by women; the average tenure of female NO and LM is long; 2) the home factor is accepted in some posts, but there is not the gender gap.

In the estimated analysis of the Korean company: 1) The ratio of graduation from university significantly influences promotion of both of men and women; 2) When we compare the average tenure of male and female $\mathrm{NO}$, the average tenure of male NO is long with a positive sign, and the graduation from university ratio has a negative sign. There is compulsory military service for two years for all young men. The "sticky floor" phenomenon is accepted by male NO. However, a lot of men can be promoted to higher managerial positions in their lifetime.

\section{Conclusions}

The purpose of this study is to contribute to the economic revitalization of Japan by learning from other countries through a consideration of diversity. This includes the differences between men and women known as "Gender Diversity in Management" at the company level based on the statistical methods that employ numerical data of company surveys in three countries, Japan, China, and Korea, and the differences in work-life balance of

\footnotetext{
${ }^{1}$ In the Chinese urban area, the retirement was guaranteed by a planned economy. Many women welcomed a retirement age that is reached earlier than for men (Ishizuka [15], Ch.2).

${ }^{2}$ The likelihood of the statistical model has AIC (Akaike's Information Criterion) and BIC (Bayesian Information Criterion):

$\mathrm{AIC}=-2 \cdot \ln (L)+2 k$

$\mathrm{BIC}=-2 \cdot \ln (L)+k \cdot \ln (n)$, where, $L:$ a log-likelihood, $n$ : sample size, $k$ : number of parameters.
} 
each country and men and women including major factors at the household level, and through a clarification of the mechanisms for promotion. The results of this study are as follows:

1) The disparity between men and women in the number of executives, managers, or employees by position has been recognized in Japan, China, and Korea, and when the male-female gap becomes larger, the higher one goes in the company hierarchy. The differential in Japan is largest, followed by Korea and China in that order. In recent years the "Affirmative Action system" has required large Korean companies to set a numerical target for the promotion of women, leading to women being given promotion priority over men (Ishizuka [11], Chapter 6).

2) In Japan, "Slow promotion," which is one of the characteristics of the employment system in the broader sense, was introduced. The "average age" of a subsection manager, which is an entryway for managerial positions, is the mid-forties in Japan, compared with the mid-thirties in China, a difference of ten years. In the case of department managers, the average ages were the early fifties in Japan, the mid-forties in Korea, and around the age of forty in China.

3) In China, the decisive male-female disparity is the difference in the "age of fixed retirement". The gender gap of working conditions is uncommon. The home factor disturbs the promotion slightly. Tenure is short and there is a fluid labor market.

4) In Korea, the gender gap of university graduates is small; women of high educational background tend to be in middle-sized companies. "Existence of spouses" is the home factor that has a large gender gap except "there is a pre-school child" in big companies.

5) In the estimated analysis of the Japanese company: 1) "slow promotion" was accepted by both men and women; 2) the home factor for a spouse and child decreases female NO (no title employee) and LM (Lower Manager: a subsection manager). If women choose not to marry, and give priority to their work they have a higher change of being promoted higher than LM; 3 ) the company culture of "there is little female manager because advancement in life will is higher in a man" only improves male employees' odds of being promoted. The home factor has a big gender gap, and the "glass ceiling" is accepted.

6) In the estimated analysis of the Chinese company: 1) the "sticky floor" phenomenon is accepted by women. The average tenure of female NO and LM is long; 2) the home factor is accepted in some posts, but there is not the gender gap.

7) In the estimated analysis of the Korean company: 1) the ratio of graduation from university significantly influences promotion of both of men and women; 2) when we compare the average tenure of male and female $\mathrm{NO}$, the average tenure of male NO is long with a positive sign, and the graduation from university ratio has a negative sign. There is compulsory military service for two years for all young men. The "sticky floor" phenomenon is accepted by male NO. However, a lot of men can be promoted to higher managerial positions in their lifetime.

Points one to four are shown in Table 1, while points five through seven are shown in Table 2.

From the 1970s to the start of the twenty-first century, Japan was the leading country in Asia and also led the world economically. Korea joined the Organization for Economic Cooperation and Development (OECD) in 1996 and joined the World Trade Organization (WTO) in 2001. In 2010, China surpassed Japan as the second largest economic power in the world. In addition, the economic development of the Association of Southeast Asian Nations (ASEAN) has also been remarkable, and the Asian economic region has been thriving. Among these countries, it is believed that the role played by Japan, China, and Korea in the Asian economy and world economy will continue to increase. The buildup of industry in Asia and Asian internal demand has already been emphasized, and if we consider the decline in Japan's population, the transition to a borderless economy is progressing. In the future, it is believed that mutual business advancement and the transfer of employees will increase, and based on this, the wage differential between Japan and other countries will likely shrink even though it is still large today. The labor market in Northeast Asia has already become partly integrated, and the effects on the labor market broken down by country may continue to increase.

The economic management that adopts Gender Diversity in Management and Work-Life Balance will activate for Japan's economy in the future while leaving Japanese-style employment practices partially.

\section{Acknowledgements}

I would like to thank Dr. Adam Graycar (Flinders University in Australia), Dr. Hyun-Hee Heo (Korea University), Dr. Bum Jung Kim (University of Hawaii), Dr. Feng-hua Zhou (Central China Normal University) and the 
Table 2. Empirical results of promotion in Japan, China, and Korea.

\begin{tabular}{|c|c|c|c|c|c|c|c|c|c|c|}
\hline & \multirow{2}{*}{$\begin{array}{l}\text { (Japanese Companies) } \\
\text { (explanatory variables) }\end{array}$} & \multirow[b]{2}{*}{ (Unit) } & \multicolumn{4}{|c|}{ Women } & \multicolumn{4}{|c|}{ Men } \\
\hline & & & Non title & $\begin{array}{l}\text { Lower } \\
\text { Manager }\end{array}$ & $\begin{array}{l}\text { Middle } \\
\text { Manager }\end{array}$ & $\begin{array}{l}\text { Higher } \\
\text { Manager }\end{array}$ & Non title & $\begin{array}{l}\text { Lower } \\
\text { Manager }\end{array}$ & $\begin{array}{l}\text { Middle } \\
\text { Manager }\end{array}$ & $\begin{array}{l}\text { Higher } \\
\text { Manager }\end{array}$ \\
\hline \multirow{4}{*}{$\begin{array}{l}\text { Human } \\
\text { capital } \\
\text { theory }\end{array}$} & Average Age & Avg Age & -0.01 & $0.03^{*}$ & -0.02 & 0.01 & $-0.03^{* *}$ & 0.03 & 0.002 & $-0.001^{* * * *}$ \\
\hline & Ratio of graduate University & $\%$ & -0.25 & 0.05 & -0.04 & 0.02 & $-0.22^{*}$ & -0.18 & -0.01 & 0.10 \\
\hline & Average Tenure & year & $0.17^{* * * *}$ & 0.04 & 0.05 & 0.03 & $0.14^{* * * *}$ & $0.10^{* *}$ & 0.04 & -0.06 \\
\hline & (tenure) 2 & (year) 2 & $-0.01^{* * * *}$ & -0.001 & -0.0002 & -0.0004 & $-0.003^{* * *}$ & $-0.002^{*}$ & -0.0003 & $0.002^{* *}$ \\
\hline \multirow{4}{*}{$\begin{array}{l}\text { A company } \\
\text { attribute }\end{array}$} & $\begin{array}{l}\text { Middle sized dummy } \\
\text { (employee } 81-300)\end{array}$ & $(=1)$ & $-1.76^{* * * *}$ & $-1.52^{* * * *}$ & $-1.13^{* * * *}$ & $-1.33^{* * * *}$ & $-2.18^{* * * *}$ & $-2.40^{* * * *}$ & $-2.09^{* * * *}$ & $-1.77^{* * * *}$ \\
\hline & Tertiary industry dummy & $(=1)$ & 0.02 & -0.36 & 0.02 & 0.33 & $-0.38^{* *}$ & $-0.69^{* * * *}$ & $-0.86^{* * * *}$ & $-0.54^{* * *}$ \\
\hline & $\begin{array}{c}\text { Four Prefectures } \\
\text { Around Capital dummy }\end{array}$ & $(=1)$ & $0.44^{* *}$ & $1.22^{* * * *}$ & $1.47^{* * * *}$ & $0.70^{*}$ & 0.23 & $0.80^{* * * *}$ & $0.66^{* * *}$ & $0.62^{* * *}$ \\
\hline & $\begin{array}{l}\text { Three Prefectures } \\
\text { Around Kinki dummy }\end{array}$ & $(=1)$ & 0.01 & 0.01 & $0.78^{*}$ & -0.12 & -0.12 & -0.14 & -0.10 & -0.13 \\
\hline \multirow{3}{*}{$\begin{array}{l}\text { A life } \\
\text { (household } \\
\text { level) } \\
\text { factor }\end{array}$} & ratio of spouse & $\%$ & $-0.75^{* * * *}$ & $-0.16^{* * *}$ & -0.01 & $-0.03^{*}$ & -0.20 & $-0.46^{* *}$ & -0.32 & $-0.23^{* * *}$ \\
\hline & Ratio of preschool child & $\%$ & -0.25 & 0.54 & 0.09 & 0.14 & $-1.17^{*}$ & -0.51 & -0.55 & -0.02 \\
\hline & Ratio of under high school child & $\%$ & -0.81 & $-0.80^{* * *}$ & -0.13 & -0.26 & -0.15 & 0.58 & 0.27 & 0.01 \\
\hline \multirow{6}{*}{$\begin{array}{l}\text { The } \\
\text { personnel } \\
\text { affairs' } \\
\text { view about } \\
\text { the factor } \\
\text { that there } \\
\text { are few } \\
\text { women's } \\
\text { manager }\end{array}$} & $\begin{array}{l}\text { View 1) man does not have a } \\
\text { burden of housework, } \\
\text { child care and the care }\end{array}$ & $(1 \& 2=1)$ & 0.43 & 0.32 & 0.52 & 0.07 & 0.20 & 0.40 & 0.50 & 0.29 \\
\hline & $\begin{array}{l}\text { View 2) man does not have } \\
\text { the pregnancy, delivery }\end{array}$ & $(1 \& 2=1)$ & -0.23 & -0.26 & $-1.50^{* *}$ & -0.66 & -0.10 & -0.32 & $-0.68^{*}$ & -0.39 \\
\hline & $\begin{array}{l}\text { View 4) man has ability } \\
\text { than a woman }\end{array}$ & $(1 \& 2=1)$ & -0.30 & -0.36 & -0.27 & 0.06 & -0.32 & -0.13 & -0.24 & -0.09 \\
\hline & $\begin{array}{l}\text { View 5) personnel affairs' } \\
\text { stuff is almost men }\end{array}$ & $(1 \& 2=1)$ & 0.22 & 0.24 & 0.51 & 0.14 & 0.09 & 0.02 & 0.06 & 0.23 \\
\hline & $\begin{array}{l}\text { View 6) man is higher motivation } \\
\text { for promotion than women }\end{array}$ & $(1 \& 2=1)$ & 0.11 & 0.21 & 0.47 & 0.26 & 0.28 & $0.50^{* *}$ & $0.73^{* * * *}$ & $0.63^{* * *}$ \\
\hline & $\begin{array}{l}\text { View 7) woman doesn't want to } \\
\text { continue working for long run }\end{array}$ & $(1 \& 2=1)$ & $0.50^{* *}$ & 0.41 & 0.33 & 0.05 & $0.41^{* *}$ & 0.26 & 0.20 & 0.12 \\
\hline \multirow{8}{*}{ Test } & Constant term & & $5.66^{* * * *}$ & $2.02^{* *}$ & $3.07^{* *}$ & $1.88^{*}$ & $7.51^{* * * *}$ & $4.05^{* * * *}$ & $5.03^{* * * *}$ & $4.77^{* * * *}$ \\
\hline & lnalpha_cons & & 0.01 & $0.26^{* *}$ & 0.19 & 0.11 & 0.08 & $0.28^{* * *}$ & $0.22^{* *}$ & -0.03 \\
\hline & Log likelihood & & -1039.2 & -571.4 & -391.8 & -273.1 & -1224.9 & -940.9 & -899.2 & -763.5 \\
\hline & $\begin{array}{c}\text { AIC } \\
\text { (Akaike information criterion) }\end{array}$ & & 2118.5 & 1182.8 & 823.5 & 586.1 & 2489.7 & 1921.8 & 1838.4 & 1566.9 \\
\hline & $\begin{array}{c}\text { BIC } \\
\text { (Bayes information criterion) }\end{array}$ & & 2182.6 & 1241.0 & 875.4 & 633.3 & 2554.1 & 1985.2 & 1902.2 & 1630.7 \\
\hline & LR chi2 & & $211.1^{* * * *}$ & $131.4^{* * * *}$ & $81.0^{* * * *}$ & $49.2^{* * * *}$ & $221.9^{* * * *}$ & $221.9^{* * * *}$ & $217.5^{* * * *}$ & $223.5^{* * * *}$ \\
\hline & Pseudo R2 & & 0.09 & 0.10 & 0.09 & 0.08 & 0.08 & 0.11 & 0.11 & 0.13 \\
\hline & Number of obs & & 182 & 136 & 99 & 78 & 185 & 176 & 179 & 179 \\
\hline
\end{tabular}




\begin{tabular}{|c|c|c|c|c|c|c|c|c|c|c|}
\hline \multicolumn{3}{|c|}{ (Chinese Companies) } & \multicolumn{4}{|c|}{ Women } & \multicolumn{4}{|c|}{ Men } \\
\hline & (explanatory variables) & (Unit) & Non title & $\begin{array}{l}\text { Lower } \\
\text { Manager }\end{array}$ & $\begin{array}{l}\text { Middle } \\
\text { Manager }\end{array}$ & $\begin{array}{l}\text { Higher } \\
\text { Manager }\end{array}$ & Non title & $\begin{array}{l}\text { Lower } \\
\text { Manager }\end{array}$ & $\begin{array}{l}\text { Middle } \\
\text { Manager }\end{array}$ & $\begin{array}{l}\text { Higher } \\
\text { Manager }\end{array}$ \\
\hline \multirow{4}{*}{$\begin{array}{l}\text { Human } \\
\text { capital } \\
\text { theory }\end{array}$} & Average Age & Avg Age & -0.02 & 0.03 & $-0.07^{* * * *}$ & 0.01 & $-0.06^{* *}$ & -0.02 & $-0.05^{* * * *}$ & $-0.03^{* * * *}$ \\
\hline & Ratio of graduate University & $\%$ & -0.28 & $-0.68^{* * *}$ & $-1.36^{* * * *}$ & $-5.99^{* * * *}$ & -0.08 & $-1.03^{* * * *}$ & $-1.38^{* * * *}$ & $-3.63^{* * * *}$ \\
\hline & Average Tenure & year & $1.19^{* * * *}$ & $0.40^{* *}$ & 0.12 & -0.03 & 0.39 & 0.09 & $0.15^{* *}$ & -0.01 \\
\hline & (tenure) 2 & (year) 2 & $-0.16^{* * * *}$ & $-0.03^{* *}$ & -0.003 & 0.003 & -0.04 & 0.004 & -0.01 & 0.0004 \\
\hline \multirow{4}{*}{$\begin{array}{l}\text { A company } \\
\text { attribute }\end{array}$} & $\begin{array}{l}\text { Middle sized dummy } \\
\text { (employee100 - 499) }\end{array}$ & $(=1)$ & $-1.71^{* * * *}$ & $-1.55^{* * * *}$ & $-1.16^{* * * *}$ & $-0.89^{* * * *}$ & $-1.81^{* * * *}$ & $-1.31^{* * * *}$ & $-1.03^{* * * *}$ & $-0.97^{* * * *}$ \\
\hline & Tertiary industry dummy & $(=1)$ & 0.15 & -0.15 & 0.10 & 0.02 & -0.11 & $-0.25^{* * *}$ & $-0.25^{* * *}$ & -0.08 \\
\hline & Shanghai City dummy & $(=1)$ & 0.01 & -0.09 & -0.12 & -0.05 & 0.05 & $-0.70^{* * * *}$ & $-0.36^{* * *}$ & -0.06 \\
\hline & Guangzhou City dummy & $(=1)$ & $-0.28^{*}$ & $-0.32^{* *}$ & -0.06 & -0.06 & -0.24 & $-0.52^{* * * *}$ & $-0.47^{* * * *}$ & -0.13 \\
\hline \multirow{3}{*}{$\begin{array}{l}\text { A life } \\
\text { (household } \\
\text { level) } \\
\text { factor }\end{array}$} & ratio of spouse & $\%$ & $2.35^{* * *}$ & $-1.84^{* * * *}$ & $0.63^{*}$ & -0.07 & $1.70^{* *}$ & -0.02 & -0.24 & $-1.03^{* * * *}$ \\
\hline & Ratio of preschool child & $\%$ & $-5.49^{* * * *}$ & -0.61 & $-1.29^{* * * *}$ & -0.17 & $-6.86^{* * * *}$ & $-2.25^{* * * *}$ & $-1.06^{*}$ & -0.31 \\
\hline & Ratio of under high school child & $\%$ & $-5.54^{* * * *}$ & -0.17 & $-0.65^{* *}$ & -0.06 & $-3.00^{* *}$ & -1.17 & 0.21 & -0.14 \\
\hline \multirow{7}{*}{$\begin{array}{l}\text { The } \\
\text { personnel } \\
\text { affairs' } \\
\text { view about } \\
\text { the factor } \\
\text { that there } \\
\text { are few } \\
\text { women's } \\
\text { manager }\end{array}$} & $\begin{array}{l}\text { view 1) man does not have } \\
\text { a burden of housework, } \\
\text { child care and the care }\end{array}$ & $(1 \& 2=1)$ & $-0.47^{* *}$ & $-0.87^{* * * *}$ & $-0.53^{* * * *}$ & $-0.36^{* *}$ & $-0.43^{* *}$ & $-0.41^{* *}$ & $-0.45^{* * *}$ & -0.09 \\
\hline & $\begin{array}{l}\text { view 2) man does not have } \\
\text { the pregnancy, delivery }\end{array}$ & $(1 \& 2=1)$ & $0.39^{*}$ & $0.60^{* * *}$ & $0.46^{* * *}$ & $0.42^{*}$ & $0.53^{* *}$ & 0.21 & $0.38^{* *}$ & 0.14 \\
\hline & $\begin{array}{l}\text { view } 3 \text { ) male employee is given } \\
\text { a certain responsibility } \\
\text { working fine opportunity }\end{array}$ & $(1 \& 2=1)$ & 0.29 & -0.05 & $-0.26^{*}$ & 0.05 & 0.28 & 0.02 & -0.07 & -0.11 \\
\hline & $\begin{array}{l}\text { view 4) man has ability } \\
\text { than a woman }\end{array}$ & $(1 \& 2=1)$ & 0.25 & $0.36^{* *}$ & 0.21 & -0.03 & $0.46^{* *}$ & $0.30^{* *}$ & $0.31^{* *}$ & 0.09 \\
\hline & $\begin{array}{l}\text { view 5) personnel affairs' } \\
\text { stuff is almost men }\end{array}$ & $(1 \& 2=1)$ & $-0.68^{* * * *}$ & $-0.43^{* * *}$ & $-0.31^{* *}$ & -0.23 & $-0.63^{* * *}$ & -0.21 & -0.18 & -0.07 \\
\hline & $\begin{array}{l}\text { view 6) man is higher motivation } \\
\text { for promotion than women }\end{array}$ & $(1 \& 2=1)$ & $0.77^{* * * *}$ & $0.52^{* * *}$ & $0.42^{* * *}$ & $0.50^{* * *}$ & $0.77^{* * * *}$ & $0.31^{*}$ & $0.33^{* *}$ & $0.26^{*}$ \\
\hline & $\begin{array}{l}\text { view 7) woman doesn't want } \\
\text { to continue working for long run }\end{array}$ & $(1 \& 2=1)$ & $-0.35^{*}$ & 0.07 & -0.10 & $-0.28^{* *}$ & $-0.42^{* *}$ & $-0.38^{* * *}$ & $-0.43^{* * * *}$ & $-0.28^{* *}$ \\
\hline \multirow{8}{*}{ Test } & Constant term & & $5.52^{* * * *}$ & $3.50^{* * * *}$ & $5.95^{* * * *}$ & $7.27^{* * * *}$ & $8.42^{* * * *}$ & $6.07^{* * * *}$ & $6.62^{* * * *}$ & $8.04^{* * * *}$ \\
\hline & lnalpha_cons & & $-0.16^{* *}$ & $-0.46^{* * * *}$ & $-0.88^{* * * *}$ & $-1.12^{* * * *}$ & -0.09 & $-0.57^{* * * *}$ & $-0.84^{* * * *}$ & $-1.14^{* * * *}$ \\
\hline & Log likelihood & & -1885.2 & -1188.3 & -917.1 & -641.2 & -1925.4 & -1240.9 & -1038.7 & -762.6 \\
\hline & $\begin{array}{c}\text { AIC } \\
\text { (Akaike information criterion) }\end{array}$ & & 3810.3 & 2416.7 & 1874.2 & 1322.3 & 3890.8 & 2521.8 & 2117.4 & 1565.1 \\
\hline & $\begin{array}{c}\text { BIC } \\
\text { (Bayes information criterion) }\end{array}$ & & 3883.2 & 2489.5 & 1947.0 & 1393.7 & 3963.7 & 2594.6 & 2190.2 & 1638.0 \\
\hline & LR chi2 & & $316.7^{* * * *}$ & $256.9^{* * * *}$ & $224.7^{* * * *}$ & $142.0^{* * * *}$ & $305.1^{* * * *}$ & $262.5^{* * * *}$ & $237.2^{* * * *}$ & $209.2^{* * * *}$ \\
\hline & Pseudo R2 & & 0.078 & 0.098 & 0.109 & 0.100 & 0.073 & 0.096 & 0.103 & 0.121 \\
\hline & Number of obs & & 282 & 282 & 281 & 262 & 282 & 282 & 282 & 282 \\
\hline
\end{tabular}




\begin{tabular}{|c|c|c|c|c|c|c|c|c|c|c|}
\hline \multicolumn{3}{|c|}{ (Korean Companies) } & \multicolumn{4}{|c|}{ Women } & \multicolumn{4}{|c|}{ Men } \\
\hline & (explanatory variables) & (Unit) & Non title & $\begin{array}{l}\text { Lower } \\
\text { Manager }\end{array}$ & $\begin{array}{l}\text { Middle } \\
\text { Manager }\end{array}$ & $\begin{array}{l}\text { Higher } \\
\text { Manager }\end{array}$ & Non title & $\begin{array}{l}\text { Lower } \\
\text { Manager }\end{array}$ & $\begin{array}{l}\text { Middle } \\
\text { Manager }\end{array}$ & $\begin{array}{l}\text { Higher } \\
\text { Manager }\end{array}$ \\
\hline \multirow{4}{*}{$\begin{array}{l}\text { Human } \\
\text { apital } \\
\text { theory }\end{array}$} & Average Age & Avg Age & $0.03^{* * *}$ & -0.03 & -0.003 & $-0.07^{* *}$ & $0.04^{* * * *}$ & -0.03 & -0.01 & 0.01 \\
\hline & Ratio of graduate University & $\%$ & -0.11 & $0.55^{* *}$ & $0.45^{*}$ & -0.07 & $-0.71^{* * * *}$ & -0.05 & $0.52^{* *}$ & $1.13^{* * * *}$ \\
\hline & Average Tenure & year & $-0.12^{*}$ & 0.04 & 0.01 & $0.15^{* *}$ & $0.09^{* *}$ & -0.04 & $0.07^{*}$ & 0.02 \\
\hline & (tenure) 2 & (year) 2 & 0.01 & -0.002 & -0.001 & $-0.004^{*}$ & $-0.004^{*}$ & $0.003^{*}$ & -0.001 & 0.0002 \\
\hline \multirow{3}{*}{$\begin{array}{l}\text { A company } \\
\text { attribute }\end{array}$} & $\begin{array}{l}\text { Middle sized dummy } \\
\text { (employee100 - 299) }\end{array}$ & $(=1)$ & $-1.95^{* * * *}$ & $-0.99^{* * * *}$ & $-0.97^{* * * *}$ & 0.08 & $-1.26^{* * * *}$ & $-0.92^{* * * *}$ & $-0.79^{* * * *}$ & $-0.89^{* * * *}$ \\
\hline & Tertiary industry dummy & $(=1)$ & 0.10 & $0.71^{* * * *}$ & $0.75^{* * * *}$ & 0.13 & -0.03 & 0.02 & $-0.28^{* *}$ & $-0.48^{* * * *}$ \\
\hline & Seoul City dummy & $(=1)$ & $0.42^{* * *}$ & $0.35^{* *}$ & $0.34^{* *}$ & $0.56^{* *}$ & -0.06 & $0.32^{* *}$ & $0.60^{* * * *}$ & $0.67^{* * * *}$ \\
\hline \multirow{3}{*}{$\begin{array}{l}\text { A life } \\
\text { (household } \\
\text { level) } \\
\text { factor }\end{array}$} & ratio of spouse & $\%$ & 0.13 & 0.09 & -0.30 & 0.44 & -0.36 & 0.13 & -0.54 & -0.70 \\
\hline & Ratio of preschool child & $\%$ & $0.46^{* *}$ & 0.11 & 0.39 & -0.04 & $0.35^{* *}$ & 0.19 & 0.08 & $0.74^{*}$ \\
\hline & Ratio of under high school child & $\%$ & 0.25 & 0.37 & 0.01 & 0.07 & 0.30 & $0.74^{* * *}$ & -0.01 & 0.39 \\
\hline \multirow{7}{*}{$\begin{array}{l}\text { The } \\
\text { personnel } \\
\text { affairs' } \\
\text { view about } \\
\text { the factor } \\
\text { that there } \\
\text { are few } \\
\text { women's } \\
\text { manager }\end{array}$} & $\begin{array}{l}\text { view 1) man does not have } \\
\text { a burden of housework, } \\
\text { child care and the care }\end{array}$ & $(1 \& 2=1)$ & 0.34 & 0.13 & 0.17 & 0.09 & 0.04 & -0.12 & 0.02 & $-0.41^{* *}$ \\
\hline & $\begin{array}{l}\text { view 2) man does not have } \\
\text { the pregnancy, delivery }\end{array}$ & $(1 \& 2=1)$ & $-0.51^{* * *}$ & $0.39^{* *}$ & $0.51^{* *}$ & 0.49 & 0.03 & 0.28 & $0.28^{*}$ & 0.31 \\
\hline & $\begin{array}{l}\text { view } 3 \text { ) male employee is } \\
\text { given a certain responsibility } \\
\text { working fine opportunity }\end{array}$ & $(1 \& 2=1)$ & -0.06 & -0.11 & 0.20 & -0.06 & 0.03 & -0.13 & 0.12 & -0.05 \\
\hline & $\begin{array}{l}\text { view 4) man has ability } \\
\text { than a woman }\end{array}$ & $(1 \& 2=1)$ & -0.30 & 0.09 & -0.29 & -0.27 & 0.16 & -0.13 & $-0.35^{* *}$ & 0.001 \\
\hline & $\begin{array}{l}\text { view 5) personnel affairs' } \\
\text { stuff is almost men }\end{array}$ & $(1 \& 2=1)$ & 0.21 & -0.09 & 0.05 & 0.23 & $0.20^{*}$ & 0.06 & $0.23^{*}$ & $0.51^{* * *}$ \\
\hline & $\begin{array}{l}\text { view } 6 \text { ) man is higher motivation } \\
\text { for promotion than women }\end{array}$ & $(1 \& 2=1)$ & -0.09 & 0.11 & $-0.35^{* *}$ & 0.28 & -0.02 & $0.30^{* *}$ & -0.004 & $-0.27^{*}$ \\
\hline & $\begin{array}{l}\text { view 7) woman doesn't want } \\
\text { to continue working for long run }\end{array}$ & $(1 \& 2=1)$ & $0.35^{* *}$ & 0.06 & -0.05 & -0.18 & -0.12 & -0.05 & 0.02 & $0.24^{*}$ \\
\hline \multirow{8}{*}{ Test } & Constant term & & $3.95^{* * * *}$ & $2.41^{* * *}$ & $1.49^{*}$ & 1.92 & $4.12^{* * * *}$ & $4.37^{* * * *}$ & $3.34^{* * * *}$ & $1.65^{*}$ \\
\hline & lnalpha_cons & & 0.02 & -0.18 & -0.21 & $-0.61^{* * *}$ & $-0.61^{* * * *}$ & $-0.33^{* * * *}$ & $-0.27^{* * *}$ & -0.07 \\
\hline & Log likelihood & & -1340.9 & -758.7 & -612.5 & -208.1 & -1494.1 & -1095.3 & -1201.5 & -998.7 \\
\hline & $\begin{array}{c}\text { AIC } \\
\text { (Akaike information criterion) }\end{array}$ & & 2719.9 & 1555.4 & 1263.0 & 454.2 & 3026.2 & 2228.6 & 2441.0 & 2035.5 \\
\hline & $\begin{array}{c}\text { BIC } \\
\text { (Bayes information criterion) }\end{array}$ & & 2788.8 & 1619.9 & 1325.4 & 502.1 & 3095.2 & 2296.0 & 2509.5 & 2104.2 \\
\hline & LR chi2 & & $229.0^{* * * *}$ & $100.9^{* * * *}$ & $97.2^{* * * *}$ & $25.4^{*}$ & $207.1^{* * * *}$ & $89.6^{* * * *}$ & $89.7^{* * * *}$ & $136.1^{* * * *}$ \\
\hline & Pseudo R2 & & 0.079 & 0.062 & 0.074 & 0.058 & 0.065 & 0.039 & 0.036 & 0.064 \\
\hline & Number of obs & & 278 & 221 & 197 & 92 & 279 & 256 & 271 & 275 \\
\hline
\end{tabular}

Data Source: "The Corporate Survey on the Human Resources Utilization of Men and Women (China, Korea) 2013", "the Corporate Survey on the Human Resources Utilization of Men and Women (Japan) 2015". Note 1: Estimating the "Negative Binominal Regression Model" with "variance is a quadratic function". Note 2: $* * * *, * * *, * *$ and $*$ denote the estimated coefficients are statistically significant at the $0.1 \%, 1 \%, 5 \%$ and $10 \%$ levels, respectively. 
12th Annual Conference of the East Asian Social Policy (at National University of Singapore) in July 2015, Dr. Seiichi Matsukawa (Tokyo Gakugei University) and the Annual Conference of JAFFE (at Tokyo Women's University) in May 2015, Dr. Naoko Hara (Hosei University) and the Annual Conference of Economics (at Hitotsubashi University in Tokyo) in November 2015 and Dr. Kazuo Yamaguchi (Chicago University).

The Chinese and Korean data is from "the Corporate Survey on the Human Resources Utilization of Men and Women (China, Korea) 2013" of the Research Institute of Economy, Trade and Industry (RIETI), which was conducted after the applicants were selected by the project. Of course, the author has the responsibility for the contents of an article.

\section{References}

[1] Ishizuka, H. (2015) Female Leaders' Careers in Corporations and the Japanese Government's "Shining Women Strategy" to Increase the Ratio of Women Leaders. Sanno College Bulletin, 48, $17-31$. http://ci.nii.ac.jp/naid/110009905138

[2] Ishizuka, H. (2014) Gender Diversity in Management in Japan Is Finally Emerging: Comparison with China and South Korea. VoxEU Column 10 July. http://www.voxeu.org/article/gender-diversity-management-japan

[3] Lazear, E.P. and Rosen, S. (1990) Male-Female Wage Differentials in Job Ladders. Journal of Labor Economics, 8, 106-122. http://www.journals.uchicago.edu/doi/abs/10.1086/298246 http://dx.doi.org/10.1086/298246

[4] Bihagen, E. and Ohls, M. (2006) The Glass Ceiling-Where Is It? Women's and Men's Career Prospects in the Private vs. the Public Sector in Sweden 1979-2000. The Sociological Review, 54, 20-47. http://dx.doi.org/10.1111/j.1467-954X.2006.00600.x

[5] Booth, A.F., Francesconi, M. and Frank, J. (2003) A Sticky Floors Model of Promotion, Pay and Gender. European Economic Review, 47, 295-322. http://dx.doi.org/10.1016/S0014-2921(01)00197-0 http://econpapers.repec.org/article/eeeeecrev/v_3a47_3ay_3a2003_3ai_3a2_3ap_3a295-322.htm

[6] Hultin, M. (2001) Gendered Promotion Processes in the Labor Market: Do Inequalities Accrue or Attenuate? In: Jonsson, J.O. and Mills, C., Eds., Cradle to Grave, Life-Course Change in Modern Sweden, Sociology Press, Durham, 141159.

[7] Albrecht, J., Bjorklund, A. and Vroman, S. (2003) Is There a Glass Ceiling in Sweden? Journal of Labor Economics, 21, 145-177. http://www.journals.uchicago.edu/doi/abs/10.1086/344126 http://dx.doi.org/10.1086/344126

[8] Duraisamy, M. and Duraisamy, P. (2016) Gender Wage Gap across the Wage Distribution in Different Segments of the Indian Labour Market, 1983-2012: Exploring the Glass Ceiling or Sticky Floor Phenomenon. Applied Economics, 48, 1-14. http://www.tandfonline.com/doi/full/10.1080/00036846.2016.1150955 http://dx.doi.org/10.1080/00036846.2016.1150955

[9] Matsushige, T. and Xu, X. (2002) Promotion and Wage of Middle Managers on Japanese Company in Japan. In Osaka University Discussion Paper 2002-J-019.

[10] Ishizuka, H. (2014) Real Condition and Problem of Gender Diversity in Management in Japan, China, and South Korea: As a Result of 605 Companies' Survey by “the Corporate Survey on the Human Resources Utilization of Men and Women (China, Korea) 2013”. RIETI (Ministry of Economy, Trade and Industry in Japan) Discussion Paper Series 14-J-010. http://www.rieti.go.jp/en/publications/summary/14020002.html

[11] Ishizuka, H. (2014) Does Gender Diversity in Management Contribute to Profitability, Productivity and AA System in Japan, China and Korea? RIETI (Ministry of Economy, Trade and Industry in Japan) Discussion Paper Series 14-J-029. http://www.rieti.go.jp/en/publications/summary/14050010.html

[12] Ishizuka, H. (2008) Labor Market and Gender in Beijing, Soul and Japan. In: Shinotsuka, E. and Nagase, N., Eds., Declining Birth Rates and Economy: East Asia of Panel Data Analysis, Sakuhinsha, Chapter 2, 40-58. http://www.lib.ocha.ac.jp/opc/recordID/catalog.bib/BA8541782X?caller=xc-search

[13] The Department of Economic and Social Affairs, United Nations (2015) The 2015 Revision of World Population Prospects. http://esa.un.org/unpd/wpp/DataQuery/ http://esa.un.org/unpd/wpp/Download/Standard/Fertility/

[14] (2010) The Chinese National Census.

[15] Ishizuka, H. (2010) Economic Analysis of Chinese Labor Market: Working Behavior of Chinese Men and Women in Urban Areas analyzed in terms of Economic and Social Systems. Keisoshobo, ISBN 978-4-326-60229-2. http://www.keisoshobo.co.jp/book/b62358.html

[16] Ishizuka, H. (2014) An Empirical Analysis of 'the Type of Full-Tame Housewives in the Developed Countries': With 
CGSS2006 and 2008. The Journal of Ohara Institute for Social Research, 667, 51-70.

http://oisr-org.ws.hosei.ac.jp/images/oz/contents/667-10.pdf

[17] Hilbe, J.M. (2011) Negative Binomial Regression. 2nd Edition, Cambridge University Press, Cambridge, UK. http://dx.doi.org/10.1017/CBO9780511973420 